\title{
I.K. Mopap,
}

\section{Ю.А. Бодяка,}

\section{Н.М. Піиула}

Вищий державний навчальний заклад України "Буковинський державний медичний університет", м. Чернівці Хмельницька міська дитяча лікарня Чернівецький медичний коледж Вищий державний навчальний заклад України "Буковинський державний медичний університет"

\section{МІСЦЕВА РОЛЬ ІНТЕРЛЕЙКІНУ-1В У РОЗВИТКУ ХРОНІЧНОГО ЗАПАЛЕННЯ ГЛОТКОВОГО ТА ПІДНЕБІННИХ МИГДАЛИКІВ У ДІТЕЙ}

Ключові слова: інтерлейкін-1 $\beta$, глотковий мигдалик, піднебінний мигдалик, хронічний аденоїдт, хронічний тонзиліт.

\begin{abstract}
Резюме. Досліджено вміст інтерлейкіну-1 $\beta$ в тканинах глоткового і піднебінних мигдаликів у дітей хворих на аденоїдит та тонзиліт із хронічним перебігом. Встановлено, щзо у дітей хворих на хронічний аденоїдит вміст інтерлейкін-1 $\beta$ в тканині глоткового мигдалика вищий в 1,8 раза $(p<0,001)$ ніж у пацуієнтів із хронічним тонзилітом.

Встановлено прямі кореляційні зв'язки сильної сили між рівнем інтерлейкіну-1 в в тканині глоткового і піднебінних мигдаликів та частотою звернень до лікувально-профілактичних закладів $з$ приводу гострих респіраторних вірусних захворювань, а також кількістю еритроцитів периферичної крові.
\end{abstract}

\section{Вступ}

Хронічні захворювання мигдаликів глотки $€$ одними з найбільш розповсюдженої патології верхніх дихальних шляхів у дітей. Майже кожна друга дитина, що часто хворіє, страждає на хронічний тонзиліт (XT) або аденотонзиліт. Довготривалий перебіг хронічного аденоїдиту (XА) і XТ супроводжується пригніченням неспецифічних факторів резистентності та сенсибілізацією організму, що веде до розвитку тяжких ускладнень, таких як ревматизм, гломерулонефрит та інші [1, $3,4]$.

Важлива роль у формуванні та регуляції захисних реакцій організму належить цитокінам. Саме інтерлейкін-1 $\beta$ (ІЛ-1 $\beta$ ) є одним із основних прозапальних цитокінів, який продукується макрофагами, фагоцитами та лімфоцитами. Він ініціює та регулює запальні та імунні процеси, активує нейтрофіли, Т- і В-лімфоцити, відіграє важливу роль у розвитку місцевого запального процесу [5].

Зважаючи на вище перераховані функції даного цитокіну, вирішено дослідити його роль у розвитку хронічного запалення глоткового та піднебінних мигдаликів дітей. Це дасть змогу більш об'єктивно оцінити клінічний перебіг даних захворювань, прогнозувати їх наслідки.

\section{Мета дослідження}

Визначити вміст ІЛ-1 $\beta$ в тканинах глоткового $\mathrm{i}$ піднебінних мигдаликів у дітей хворих на ХА і XТ, а також провести кореляційно-регресивний аналіз із частотою звернень до лікувально-профілактичних закладів з приводу гострих респіраторних вірусних захворювань (ГРВЗ) та кількістю еритроцитів периферичної крові.

\section{Матеріал і методи}

Обстежено 16 дітей хворих на XА та 12 - на $\mathrm{XT}$, які перебували на лікуванні в оториноларингологічному відділенні Хмельницької міської дитячої лікарні. Середній вік дітей становив 5,14 0,06 років.

Всім пацієнтам виконано адено- або тонзілотомію. Забір матеріалу проводили під час оперативного втручання. Тканину глоткового мигдалика вагою до 50 мг поміщали в 1 мл фізіологічного розчину та перетирали.

Вміст ІЛ-1 $\beta$ в отриманому біоптаті визначали за допомогою імуноферментного методу з використанням наборів реагентів фірми "ВЕКТОРБЕСТ" (Росія). Вимірювання проводили на імуноферментному аналізаторі "Stat Fax 303" (США). Концентрацію ІЛ-1 $\beta$ визначали в мг/мл і перераховували за формулою $\mathrm{a}=(\mathrm{x}+1) * \mathrm{y} / \mathrm{x}$, де $\mathrm{a}$ вміст у мг/г тканини слизової оболонки; $\mathrm{x}$ - вага шматка слизової оболонки; 1 - об'єм фізіологічного розчину; у - концентрація у пг/мл.

Кількість звернень до лікувально-профілактичних закладів 3 приводу ГРВЗ за останній рік 
визначали із медичних карток амбулаторного хворого.

Також всім особам виконували загальний аналіз крові з обов'язковим визначенням кількості еритроцитів пробірочним методом із підрахунком у камері Горяєва.

Статистичну обробку отриманих результатів досліджень проведено із використанням програми StatSoft Statistica 6,0. Оцінювали середні значення показників ІЛ-1 $\beta$ тканини носоглоткової мигдалини, а також еритроцитів та лімфоцитів периферичної крові (М), їхні стандартні відхилення (m), достовірність статистичних показників (p) за критерієм Стьюдента.

Кореляційно-регресивний аналіз проводили шляхом оцінки параметрів лінійної функції з можливістю визначення лінійного коефіцієнта кореляції Пірсона (r), з метою встановлення можливого зв'язку між кількістю звернень до лікувально-профілактичних закладів з приводу ГРВЗ та показниками ІЛ-1 $\beta$ в тканині піднебінних мигдаликів, а також еритроцитами периферичної крові. Направленість зв'язку визначали за знаком коефіцієнта кореляції, а силу кореляційного зв'язку (КЗ) за наступною шкалою: слабка сила зв'язку - 0 - 0,29, середня сила 0,3 - 0,69, та сильна сила кореляційного зв'язку - 0,7 - 0,99 [2].

\section{Обговорення результатів дослідження}

Отримані результати дослідження стосовно вмісту ІЛ-1 $\beta$ у тканинах піднебінних та носоглоткового мигдаликів, свідчать про вірогідне переважання останніх в 1,8 раза $(\mathrm{p}<0,001)$. Так, вміст ІЛ-1 $\beta$ у хворих на ХА складає $22,35 \pm 1,78$ мг/г, а у пацієнтів із ХT - 12,4 $\pm 0,89$ мг/г.

Досліджено середню кількість звернень до лікувально-профілактичних закладів 3 приводу ГРВ3, за останній рік перед оперативним втручанням. Результати дослідження свідчать про переважання показника в групі дітей хворих на ХА. Так, середня кількість звернень при ХА становить 5,88 \pm 0,52 раз на рік, а при ХТ - 4,08 $\pm 0,63$ раз на рік, що на $30,61 \%(\mathrm{p}<0,05)$ менша.

Встановили сильний прямий К3 (r=0,763; $\mathrm{p}=0,05)$ між кількістю звернень з приводу ГРВ3 та вмістом ІЛ-1 $\beta$ в глотковому мигдалику. При досліджені КЗ між кількістю звернень до лікувально-профілактичних закладів та вмістом ІЛ-1 $\beta$ в піднебінних мигдаликах визначаються також сильні зв'язки ( $\mathrm{r}=0,772 ; \mathrm{p}=0,05)$.

У хворих на XА і XT має місце утруднення носового дихання, що призводе до змін в периферичній крові. Це насамперед компенсаторний еритроцитоз, що є наслідком постійного гіпоксичного стану. У дітей із ХА кількість ерит- роцитів периферичної крові становила 4,8 $\pm 0,08$ * $10^{12} /$ л, а із XТ - 4,27 $\pm 0,05 * 10^{12} /$ л, що на $11,04 \%$ $(<0,001)$ менше.

3 метою визначення можливого взаємозв'язку вмісту ІЛ-1 $\beta$ в тканині глоткового та піднебінних мигдаликів на рівень еритроцитів периферичної крові проведено кореляційно-регресивний аналіз між цими показниками.

При дослідженні КЗ між ІЛ-1 $\beta$ тканини глоткового мигдалика та еритроцитами периферичної крові у дітей хворих на ХА, встановлено сильний прямий К3 (r=0,849; $\mathrm{p}=0,05)$. У дітей хворих на XТ відмічається прямий КЗ середньої сили $(\mathrm{r}=0,346$; $\mathrm{p}=0,05)$ між ІЛ-1 $\beta$ тканини піднебінної мигдалини та еритроцитами периферичної крові.

Підсумовуючи результати проведеного дослідження слід зазначити, що у дітей хворих на ХА відмічено вищий вміст ІЛ-1 $\beta$ в тканині глоткового мигдалика порівняно з хворими на ХT.

У дітей хворих на ХА встановлено наявність прямого сильного КЗ між показниками ІЛ-1 $\beta$ в тканині глоткового мигдалика та еритроцитами периферичної крові.

\section{Висновки}

1.У дітей хворих на хронічний аденоїдит встановлено зростання рівня ІЛ-1 $\beta$ в порівнянні з дітьми із XT.

2.Вміст ІЛ-1 $\beta$ в глотковому та піднебінному мигдаликах асоціював із рівнем захворюваності дітей на ГРВ3.

\section{Перспективи подальших досліджень}

Вважаємо за доцільне дослідити вміст ІЛ-1 $\beta$ у сироватці дітей хворих на XА і XT.

Література. 1.Вандишева Л.В. Аденоидит и тонзиллит как проявления хронического латентного риносинусита / Л.В. Вандишева // Вестник новых медицинских технологий. 2009. - Т. XVI, № 1. - С. 147-148. 2.Вороненко Ю.В. Соціальна медицина та організація охорони здоров'я: [підручник] / Ю.В. Вороненко. - Тернопіль: Укрмедкнига, 2002 . - 332 с. 3. Особенности применения топических антибактериальных препаратов в терапии воспалительных заболеваний полости носа, носоглотки и околоносовых пазух у детей / Н.И. Васильева // Вопросы современной педиатрии. - 2012. - Т. 11, № 5. - С. 142-148. 4.Особенности проявления воспалительных заболеваний носоглотки у детей / Н.И. Потатуркина-Нестерова, А.С. Салманская, Т.Г. Смирнова [и др.] // Вопросы современной педиатрии. 2012. - № 6. - C. 145-149. 5. Komorowska A. Cytokines locally produced by lymphocytes removed from the hypertrophic nasopharyngeal and palatine tonsils / A. Komorowska // Int. J. Pediatr. Otorhinolaryngol. - 2005. - Vol. 69 (7). - P. 937-941.

\section{МЕСТНАЯ РОЛЬ ИНТЕРЛЕЙКИНА-1В В РАЗВИТИИ ХРОНИЧЕСКОГО ВОСПАЛЕНИЯ ГЛОТКОВОЙ И ПОДНЕБНОЙ МИНДАЛИН У ДЕТЕЙ}

\section{И.К. Морар, Ю.А. Бодяка, Н.Н. Пицула}

Резюме. Исследовано содержание интерлейкина- $1 \beta$ в тканях глотковой и поднебной миндалин у детей больных на 
аденоидит и тонзиллит с хроническим протеканием. Установлено, что у детей с хроническим аденоидитом больше в 1,8 раза $(\mathrm{p}<0,001)$ содержание интерлейкину-1 $\beta$ в тканях глотковой миндалины, чем у пациентов с хроническим тонзилитом.

Выявлены прямые корреляционные связи сильной силы между уровнем интерлейкина- $1 \beta$ ткани глотковой и поднебной миндалин и частотой обращений в лечебнопрофилактические заведения по-поводу острых респираторных вирусных заболеваний, а также количеством эритроцитов периферической крови.

Ключевые слова: интерлейкин- $1 \beta$, глотковая миндалина, поднебная миндалина, хронический аденоидит, хронический тонзиллит.

\section{THE LOCAL ROLE OF INTERLEUKINE-1 в IN THE DEVELOPMENT OF CHRONIC INFLAMMATION OF THE PHARYNGEAL AND PALATINE TONSILS IN CHILDREN}

I.K. Morar, Yu.A. Bodiaka, N.M. Pitsula
Abstract. Interleukine-1 $\beta$ content in the tissues of the pharyngeal and palatine tonsils in children suffering from adenoiditis and tonsillitis with chronic course was investigated. It has been determined that interleukine- $1 \beta$ content in the tissue of the pharyngeal tonsil is 1.8 time higher $(p<0,001)$ in children with chronic adenoiditis than in patients with chronic tonsillitis.

Direct correlative relations of a strong power between interleukine-1 $\beta$ level of the tissue of the pharyngeal and palatine tonsils and frequency of seeking health care in medicalpreventive institutions on the occasion of acute respiratory virus diseases as well as quantity of erythrocytes in the peripheral blood were established.

Key words: interleukine- $1 \beta$, pharyngeal tonsil, palatine tonsil, chronic adenoiditis, chronic tonsillitis.

Higher State Educational Establishment of Ukraine "Bukovinian State Medical University", Chernivtsi Clin. and experim. pathol.-2016.-Vol.15,№2(56).p.1.-P.121-123.

Надійшла до редакиії 10.04.2016 Рецензент - проф. С.А. Левицька (C) I.К. Морар, Ю.А. Бодяка, Н.М. Піиула, 2016 